\title{
MEDIASI PENAL SEBAGAI BENTUK DIVERSI DALAM PENYELESAIAN PERKARA PIDANA ANAK BERBASIS KEADILAN RESTORATIF
}

\author{
Beniharmoni Harefa \\ Fakultas Hukum \\ Universitas Pembangunan Nasional Veteran Jakarta \\ Email : beni_harefa@yahoo.com
}

\begin{abstract}
ABSTRAK
Menyelesaian perkara pidana anak melalui jalur peradilan pidana formal, dapat merusak masa depan anak. Berdasarkan UU No 11 Tahun 2012 tentang Sistem Peradilan Pidana Anak, Indonesia mengenal diversi. Diversi merupakan pengalihan penyelesaian perkara pidana anak dari peradilan pidana formal menuju peradilan pidana non formal. Salah satu bentuk alternatif penyelesaian perkara melalui jalur peradilan non formal, yakni mediasi penal. Melihat kesamaan antara konsep mediasi penal dan diversi itu, maka tulisan ini hendak mengkaji perihal kesamaan mediasi penal dan diversi. Sehingga kesamaan tersebut, diharapkan menjadi landasaan untuk dapat menggunakan mediasi penal sebagai bentuk diversi (pengalihan) dalam menyelesaikan perkara pidana anak (pelaku). Mediasi penal juga merupakan penyelesaian perkara yang berbasis pada keadilan restoratif. Keadilan restoratif menjadi pendekatan yang wajib digunakan dalam sistem peradilan pidana anak di Indonesia.
\end{abstract}

Kata Kunci : Mediasi Penal, Diversi, Peradilan Pidana Anak, Keadilan Restoratif

\section{ABSTRACT}

Settlement of juvenile delinquency cases through the formal criminal justice, can damage the child's future. Based on Law No. 11 of 2012 on the Juvenile Justice System, Indonesia recognize diversion. Diversion is the completion of the transfer of juvenile delinquency cases from the formal juvenile justice towards non-formal juvenile justice. One of the alternative forms of settling disputes through non-formal justice, namely penal mediation. See the similarity between the concept of penal mediation and diversion of it, then this paper want to study the subject in common penal mediation and diversion. So the similarities, are expected to be based on to be able to use penal mediation as a form of diversion in resolving juvenile delinquency cases children (offender). Mediation is also a penal settlement of cases based on restorative justice. Restorative justice approach that must be used in the juvenile justice system in Indonesia.

Keywords : Penal Mediation, Diversion, Juvenile Justice, Restorative Justice 


\section{Pendahuluan}

Menempatkan anak didalam sistem peradilan pidana, layaknya penjahat dewasa, merupakan hal yang kurang tepat. Mengingat kondisi kejiwaan, mental, pola pikir dari anak, masih berada pada masa perkembangan. Menyelesaian perkara pidana anak dengan jalur peradilan pidana formal, dapat merusak masa depan anak.

Proses peradilan pidana formal, cenderung menciptakan pelabelan (stigmatisasi) terhadap anak, bahkan menjadi faktor kriminogen terulangnya delinquency anak (Paulus Hadisuprapto, 2006:5).

Di Indonesia melalui UU No 11 Tahun 2012 tentang Sistem Peradilan Pidana Anak, penyelesaian perkara pidana anak, dimungkinkan diselesaikan dengan upaya diversi (pengalihan) (Setya Wahyudi, 2011:4). Artinya, bahwa penyelesaian perkara pidana anak berusaha dialihkan keluar jalur peradilan pidana formal menuju peradilan non formal.

Salah satu bentuk alternatif penyelesaian perkara melalui jalur peradilan non formal, yakni "mediasi penal". Mediasi penal berarti penyelesaian perkara pidana melalui musyawarah dengan bantuan mediator yang netral, dihadiri korban dan pelaku serta perwakilan masyarakat, dengan tujuan pemulihan bagi korban, pelaku dan lingkungan masyarakat (DS. Dewi dan Fatahillah A. Syukur, 2011:86).

Melihat kesamaan antara konsep mediasi penal dan diversi itu, maka tulisan ini hendak mengkaji perihal kesamaan mediasi penal dengan diversi. Sehingga kesamaan tersebut, diharapkan menjadi landasaan bahwa mediasi penal dapat digunakan sebagai bentuk diversi (pengalihan) khususnya dalam menyelesaikan perkara pidana anak.

Adapun rumusan masalah yang harus dijawab, sebagai batasan pembahasan dalam tulisan ini, yakni :

1. Apakah mediasi penal dapat digunakan sebagai bentuk implementasi diversi dalam menyelesaikan perkara pidana anak di Indonesia?

2. Bagaimana mediasi penal dalam penyelesaian perkara pidana anak, disebut penyelesaian perkara menuju keadilan restoratif (restorative justice)?

\section{Mediasi Penal dan Diversi}

Secara terminologinya mediasi penal berarti mediation in criminal cases, mediation in penal matters, victim offenders mediation, offender victim arrangement (Inggris), strafbemiddeling (Belanda), der AuBergerichtliche Tatausgleich (Jerman), de mediation penale (Perancis) (Lilik Mulyadi, 2011:1).

Mediasi penal merupakan salah satu bentuk alternatif penyelesaian sengketa di luar pengadilan yang biasa dikenal dengan istilah ADR atau Alternative Dispute Resolution, adapula yang menyebutnya Aproriate Dispute Resolution (Barda Nawawi, 2007:2). 
ADR pada umumnya digunakan di lingkungan kasus-kasus perdata, tidak untuk kasus-kasus pidana (Ibid). Oleh karena itu, praktek penyelesaian perkara pidana di luar pengadilan selama ini, tidak ada landasan hukum formalnya. Termasuk menggunakan mediasi penal sebagai alternatif penyelesaian perkara pidana.

Sejalan dengan mediasi penal, diversi juga dikenal sebagai proses penyelesaian perkara pidana melalui jalur non formal. Sejak berlakunya UU No 11 Tahun 2012 tentang Peradilan Pidana Anak, diversi secara tegas diatur dalam Bab II UU No 11 Tahun 2012.

Dalam Sistem Peradilan Pidana mulai dari penyidikan, penuntutan, sidang pengadilan wajib diupayakan diversi. Diversi difasilitasi oleh aparat di setiap tingkatan yakni kepolisian, penuntut umum, dan hakim.

Menurut Jack E. Bynum dalam bukunya Delinquency a sociological approach, memberikan pengertian diversi yaitu diversion is an attermpt to divert or channel out, youthful offenders from the juvenile justice system (diversi adalah sebuah tindakan atau perlakuan untuk mengalihkan atau menempatkan pelaku tindak pidana anak keluar dari sistem peradilan) (Marlina, 2013:1).

Dalam Black's Law Dictionary, divertion didefenisikan sebagai $a$ turning a side or altering the natural course or route of a thing. The term is chiefly applied to the an authorized change or alteration of the water course to the prejudice of a lower riparian, or the authorized use of funds (Henry Campbell Black, 1990:477).

\section{Mediasi Penal Sebagai Bentuk Diversi}

Dalam menganalisis dan membahas mediasi penal sebagai bentuk diversi, maka perlu mengelaborasi ide dan prinsip kerja (working principle) mediasi penal.

Adapun ide dan prinsip kerja mediasi penal (Barda Nawawi Arief, 2008:5-6), sebagai berikut

a. Penanganan konflik (Conflict Handling/ Konflikbearbeitung).

b. Berorientasi pada proses (Process Orientation; Prozessorientierung).

c. Proses Informal (Informal Proceeding - Informalitat).

d. Ada partisipasi aktif dan otonom para pihak (Active and Autonomous Participation

Parteiautonomie/Subjektivier ung).

Pertama, mediasi penal sebagai penanganan konflik yang mengupayakan para pihak (penegak hukum, pelaku, korban, masyarakat) melupakan kerangka hukum formal (sistem peradilan pidana formal). Mediasi penal mendorong para pihak terlibat dalam proses komunikasi.

Menangani konflik dengan komunikasi, tidak selalu harus dengan jalur pemidanaan, hal ini sangat relevan dengan konsep diversi (pengalihan).

Diversi (pengalihan) yang berupaya untuk menyelesaikan perkara pidana anak dengan mengupayakan para pihak 
melupakan kerangka hukum formal yang ada, sangat sesuai dengan ide dan prinsip kerja mediasi penal.

Dalam suatu perkara pidana yang pelakunya adalah anak, maka dalam rangka mengalihkan anak dari proses peradilan pidana formal, diupayakan komunikasi antara anak (pelaku), orangtua/wali anak, dengan korban dan masyarakat.

Komunikasi ini diharapkan dapat menjadi wadah untuk mencapai titik temu dalam penyelesaian perkara pidana, sehingga perkara pidana tersebut tidak mesti dibawa pada proses peradilan pidana formal.

Penanganan konflik dengan jalur komunikasi sebagai ide/ prinsip kerja mediasi penal, sangat sesuai dengan konsep diversi pada penyelesaian perkara pidana anak. Oleh sebab itu, mediasi penal dapat digunakan sebagai implementasi bentuk diversi dalam penyelesaian perkara pidana anak.

Kedua, mediasi penal yang berorientasi pada proses, yang dapat digunakan sebagai bentuk diversi. Mediasi penal lebih berorientasi pada kualitas proses daripada hasil, yaitu menyadarkan pelaku tindak pidana akan kesalahannya, kebutuhankebutuhan konflik terpecahkan, ketenangan korban dari rasa takut.

Hal ini sangat relevan dengan konsep diversi (pengalihan). Diversi berupaya untuk menyelesaikan perkara pidana anak dengan mengupayakan anak (pelaku) menyadari kesalahannya dan bertanggungjawab atas perbuatan salah yang dilakukan tersebut.

Diversi bertujuan menyelesaikan perkara pidana anak, dengan memberikan ketenangan bagi korban.
Menempatkan anak dalam proses peradilan pidana formal, belum tentu akan memberikan ketenangan bagi korban.

Namun dengan mediasi yang mempertemukan pelaku, korban dan perwakilan masyarakat, setidaknya dapat menciptakan kedamaian antara pelaku dan korban. Oleh sebab itu, mediasi penal dapat digunakan sebagai implementasi bentuk diversi dalam penyelesaian perkara pidana anak.

Ketiga, mediasi penal sebagai proses informal, yang dapat digunakan sebagai bentuk diversi. Mediasi penal merupakan suatu proses yang informal, tidak bersifat birokratis, menghindari prosedur hukum yang ketat.

Hal tersebut sangat relevan dengan konsep diversi. Konsep diversi menghindari anak agar tidak berhadapan secara langsung dengan proses peradilan yang bersifat birokratis.

Sistem peradilan pidana yang terdiri dari 4 (empat) komponen, kepolisian, kejaksaan, pengadilan dan lembaga pemasyarakatan (MardjonoReksodiputro,

2007:85), cenderung bersifat birokratis.

Sistem peradilan pidana yang diimplementasikan dalam 4 (empat) sub sistem yakni kekuasaan penyidikan, kekuasaan penuntutan, kekuasaan mengadili/ menjatuhkan pidana, dan kekuasaan eksekusi/ 
pelaksanaan pidana, (Barda Nawawi Arief, 2007:9) sangat birokratis, prosedural dan ketat.

Diversi menghindari hal ini. Penyelesaian perkara anak (pelaku) sedapat mungkin dihindari dari sifat birokratis, prosedural dan ketat ini, karena akan berdampak pada perkembangan anak.

Mediasi penal dapat digunakan sebagai bentuk diversi dalam penyelesaian perkara pidana anak.

Keempat, mediasi penal yang memberi kesempatan adanya partisipasi aktif dan otonom para pihak, yang dapat digunakan sebagai bentuk diversi.

Di dalam mediasi penal, para pihak (pelaku dan korban) tidak dilihat sebagai objek dari prosedur hukum pidana. Akan tetapi para pihak, lebih dipandang sebagai subjek yang memiliki tanggungjawab pribadi dan kemampuan untuk berbuat. Mereka diharapkan berbuat atas kehendaknya sendiri.

Hal tersebut sangat relevan dengan konsep diversi. Diversi yang berupaya untuk menyelesaikan perkara pidana anak, bermaksud memberi kesempatan bagi para pihak (pelaku, korban dan masyarakat) untuk berkomunikasi dalam menyelesaikan perkaranya.

Dalam diversi perkara anak, para pihak yang difasilitasi oleh penegak hukum dipertemukan dengan disaksikan perwakilan masyarakat dan pihak terkait lainnya bertujuan untuk bermusyawarah dan mencapai kata sepakat sehingga menghindari peradilan pidana formal.

Sejalan dengan ide dan prinsip kerja mediasi penal, diversi memberi kesempatan adanya partisipasi aktif dan otonom dari para pihak. Oleh sebab itu, mediasi penal dapat digunakan sebagai implementasi bentuk diversi dalam penyelesaian perkara pidana anak.

Mediasi penal dapat digunakan sebagai bentuk diversi (pengalihan) perkara pidana anak, semakin ditegaskan dengan menelaah substansi UU No 11 Tahun 2012 tentang Sistem Peradilan Pidana Anak. Dalam UU ini diversi diupayakan melalui musyawarah.

Musyawarah yang dimaksud tentunya tidak jauh berbeda dengan mediasi penal, yakni bermaksud mempertemukan para pihak (pelaku, korban dan masyarakat) guna mencapai kesepakatan.

Di beberapa negara, pengaturan mediasi penal, ditempatkan sebagai bagian dari Undang-Undang Peradilan Anak (The Juvenile Justice Act), yaitu di Austria, Jerman, Finlandia, dan Polandia (Barda Nawawi Arief, Op.Cit).

\section{Mediasi Penal sebagai Bentuk Diversi Berbasis Keadilan Restoratif}

Ide dan prinsip kerja mediasi penal, yang mengutamakan penyelesaian perkara dengan cara musyawarah relevan dengan bentuk diversi.

Ide dan prinsip kerja mediasi penal dalam penyelesaian perkara pidana anak dengan jalur musyawarah tersebut, juga sejalan penyelesaian perkara 
berbasis keadilan restoratif (restorative justice).

Dalam penyelesaian perkara berbasis keadilan restoratif, aparat penegak hukum memfasilitasi bertemunya tersangka dan korban serta masyarakat. Pertemuan itu, bertujuan untuk merumuskan skema penyelesaian yang terbaik dan dianggap adil oleh pihak-pihak yang bersengketa (Marcus P Gunarto, 2013:17).

Penyelesaian perkara pidana anak (pelaku), menggunakan diversi, maka diselesaikan dengan mempertemukan orangtua/wali anak dan korban serta masyarakat . Pertemuan itu difasilitasi oleh aparat penegak hukum untuk melakukan musyawarah.

Musyawarah ini layaknya mediasi penal yang juga mempertemukan pelaku, korban dan masyarakat difasilitasi oleh pihak ketiga (yang tidak terlibat dengan perkara/ netral).

Paradigma yang selama ini berkembang dalam peradilan pidana khususnya di Indonesia lebih cenderung pada pemidanaan (retributif). Paradigma tersebut digeser dengan hadirnya restorative justice. Keadilan restoratif memandang bahwa pelaku harus dipulihkan tanpa harus memidana mereka. Keadilan restoratif (restorative justice) merupakan upaya pencarian alternatif pemidanaan (selain penjara) (Barda N Arief, 2000:169).

Pada saat anak (pelaku) melakukan tindak pidana, maka pada saat yang sama dapat merusak keseimbangan tatanan masyarakat. Keseimbangan tatanan masyarakat yang terganggu haruslah dipulihkan ke keadaan semula (restitutio in integrum) atau kembali ke keadaan semula (Sudikno Mertokusumo, 1999:3).

Ide keadilan restoratif bermaksud membangun suatu keadaan yang bersifat memulihkan atau menyembuhkan dari keadaan yang sempat terganggu tersebut. Keadian restoratif menghendaki pemulihan pelaku (anak) dengan korban dan masyarakat sehingga tatanan masyarakat kembali seimbang.

Menurut Muladi, keadilan restoratif, mempunyai beberapa karakteristik (Muladi, 1995:127129) sebagai berikut:

a. Kejahatan dirumuskan sebagai pelanggaran seorang terhadap orang lain dan diakui sebagai konflik;

b. Titik perhatian pada pemecahan masalah pertanggungjawaban dan kewajiban pada masa depan;

c. Sifat normatif dibangun atas dasar dialog dan negosiasi;

d. Restitusi sebagai sarana perbaikan para pihak, rekonsiliasi dan restorasi sebagai tujuan utama;

e. Keadilan dirumuskan sebagai hubungan-hubungan hak, dinilai atas dasar hasil;

f. Sasaran perbaikan pada perbaikan kerugian sosial;

g. Masyarakat merupakan fasilitator di dalam proses restoratif;

h. Peran korban dan pelaku tindak pidana diakui, baik dalam masalah maupun dalam penyelesaian hak-hak dan kebutuhan korban. Pelaku tindak pidana 
didorong untuk bertanggungjawab;

i. Pertanggungjawaban si pelaku dirumuskan sebagai dampak pemahaman terhadap perbuatan dan untuk membantu memutuskan yang terbaik;

j. Tindak pidana dipahami dalam konteks menyeluruh, moral, sosial dan ekonomis; dan

k. Stigma dapat dihapus melalui tindakan restoratif.

Dari beberapa karakteristik di atas, terlihat jelas bahwa model penyelesaian perkara dengan pendekatan restoratif merupakan penerjemahan dari konsep mediasi penal.

Mediasi penal khususnya yang digunakan dalam menyelesaikan perkara pidana anak, dapat dikatakan sebagai penyelesaian perkara menuju pada keadilan restoratif (restorative justice)

Berdasarkan inti dalam proses restorative justice yakni membangun partisipasi bersama antara pelaku, korban dan masyarakat menyelesaikan suatu peristiwa atau tindak pidana.

Menempatkan pelaku, korban dan masyarakat sebagai "stakeholders" yang bekerjasama dan langsung berusaha menemukan penyelesaian yang dipandang adil bagi semua pihak (win-win solutions) (Bagir Manan, 2008:4).

Dalam penyelesaian perkara pidana anak, menempatkan pelaku (anak), korban dan masyarakat untuk duduk bersama dalam menyelesaian perkara pidana anak, merupakan suatu hal yang sangat tepat.

Mengingat perbuatan nakal yang dilakukan anak, tidak sama dengan kejahatan yang dilakukan oleh penjahat dewasa. Anak tetaplah anak, dengan segala kenakalannya, maka penyelesaian perkara pidana yang melibatkannya, kiranya tepat dengan upaya mediasi penal.

Aspek lainnya yang dimaksud seperti aspek moral, sosial, ekonomi, agama dan adat istiadat lokal serta berbagai pertimbangan lain. Utamanya pertimbangan kepentingan terbaik bagi anak (the best interest of the child).

Hal ini senada dengan tujuan keadilan dengan pendekatan restoratif. restorative justice merupakan sebuah penanganan tindak pidana, yang tidak hanya dilihat dari kacamata hukum semata.

Akan tetapi juga dikaitkan dengan aspek moral, sosial, ekonomi, agama dan adat istiadat lokal serta berbagai pertimbangan lain (Jeff Cristian, $\mathrm{tt}: 1)$.

Penyelesaian perkara pidana anak dengan mediasi penal sangat berperan penting guna mencapai keadilan restoratif, yang tidak hanya memandang sisi hukum saja, namun mempertimbangkan aspek lainnya.

\section{Kesimpulan}

Berdasarkan uraian di atas dapat disimpulkan beberapa hal terkait mediasi penal sebagai bentuk diversi dalam penyelesaian perkara pidana anak berbasis keadilan restoratif. 
Pertama, mediasi penal sebagai bentuk diversi (pengalihan) dalam penyelesaian perkara pidana anak di Indonesia. Hal ini dapat terlihat dari ide dan prinsip kerja mediasi penal, yang sangat sesuai dengan tujuan diversi (pengalihan) perkara anak dari proses peradilan pidana.

Kedua, mediasi penal sebagai bentuk penyelesaian perkara pidana pidana anak, sejalan dengan pendekatan menggunakan keadilan restoratif (restorative justice). Restorative justice yang berupaya menggeser paradigma selama ini bahwa penyelesaian perkara pidana harus dengan pemidaan, sesuai dengan ide dan prinsip kerja mediasi penal yang lebih mengutamakan musyawarah.

\section{Daftar Pustaka}

Barda Nawawi Arief, 2008, Mediasi Penal Penyelesaian Perkara Diluar Pengadilan, Pustaka Magister, Semarang

Barda Nawawi Arief, 2007, Mediasi Penal dalam Penyelesaian Sengketa di Luar Pengadilan, Makalah yang disampaikan dalam Seminar Nasional Pertanggungjawaban Hukum Korporasi dalam Konteks Good Corporate Governance, 27 Maret 2007, Continental Hotel, Jakarta.

Barda Nawawi Arief, 2007, Kapita Selekta Hukum Pidana Tentang Sistem Peradilan Pidana Terpadu (Integrated Criminal Justice System), Badan Penerbit Universitas Diponegoro, Semarang.

Bagir Manan, 2008, Restorative Justice (Suatu Perkenalan) : Refleksi Dinamika Hukum Rangkaian
Pemikiran Dalam Dekade

Terakhir, Perum

Percetakan Negara R.I. Jakarta.

DS. Dewi dan Fatahillah A. Syukur, 2011, Mediasi Penal : Penerapan Restorative Justice di Pengadilan Anak Indonesia, Indie-Publishing, Depok.

Henry Campbell Black, 1990, Black's Law Dictionary (Sixth Edition), St. Paul Minn West Publishing Co.

Jeff Cristian, Juvenile Justice : Keadilan Yang Memulihkan Bagi Anak, Makalah disampaikan pada Lokakarya Konsultatif Restorative Justice, Kerjasama KPAIPemerintah Swedia, Jakarta.

Lilik Mulyadi, Mediasi Penal Dalam Sistem Peradilan Pidana Pengkajian Asas, Norma, dan Praktik, Makalah Seminar hasil penelitian tentang Mediasi Penal Dalam Sistem Peradilan Pidana di Indonesia, yang diselenggarakan oleh Pusat Penelitian dan Pengembangan Hukum dan Peradilan Badan Litbang Diklat Kumdil Mahkamah Agung RI, pada tanggal 26 Oktober 2011, di Hotel Alila Pecenongan, Jakarta Pusat.

Marlina, Konsep Diversi dan Restorative Justice Dalam UU No 11 Tahun 2012 tentang Sistem Peradilan 
Pidana Anak, makalah disampaikan pada workshop tentang Restorative Justice dalam Perspektif UU Sistem Peradilan Anak dan Kearifan Lokal Masyarakat Nias, Hotel Nasional, Gunungsitoli, 21 Mei 2013.

Mardjono Reksodiputro, 2007, Hak Asasi Manusia Dalam Sistem Peradilan Pidana, Pusat Pelayanan Keadilan dan Pengabdian Hukum Lembaga Kriminologi Universitas Indonesia, Jakarta.

Marcus Priyo Gunarto, Restrukturisasi Peradilan Pidana Sebagai Upaya Mencegah Kelebihan Kapasitas Narapidana di Lembaga Pemasyarakatan, Pidato Pengukuhan Guru Besar, pada Fakultas Hukum Universitas Gadjah Mada, Yogyakarta, pada tanggal 24 Desember 2013.

Muladi, 1995, Kapita Selekta Hukum Pidana, Badan Penerbit Universitas Diponegoro, Semarang.

Paulus Hadisuprapto, Peradilan Restoratif : Model Peradilan Anak Indonesia Masa Datang, Pidato Pengukuhan Guru Besar dalam Bidang Kriminologi, Fakultas Hukum Universitas Diponegoro, Semarang, 18 Februari 2006.

Setya Wahyudi, 2011, Implementasi Ide Diversi Dalam Pembaruan Sistem Peradilan Pidana Anak di Indonesia, Genta Publishing, Yogyakarta. 